\title{
The Experience of Linguistic and Folklore Interaction in the Circumstances of the Single Cultural Space of Yakutia
}

\author{
Olga losifovna Charina ${ }^{1}$ \\ Tatiana Alexsandrovna Berdnikova² \\ Anna Semenovna Larionova ${ }^{1}$ \\ Rimma Innokentievna Vasileva ${ }^{3}$ \\ ${ }_{1}$ Yakut Folklore Department, the Institute for Humanities Research and Indigenous Studies of the North Russian Academy of \\ Sciences Siberian Branch Yakutsk, Russian Federation; Email: ochar@list.ru \\ 2Philological Faculty, Department of General Linguistics and Rhetoric, North-Eastern Federal University named after \\ M.K. Ammosov, Yakutsk, Russian Federation \\ ${ }^{3}$ Grammar and Dialectology of Yakut language Department, the Institute for Humanities Research and Indigenous Studies of the \\ North Russian Academy of Sciences Siberian Branch Yakutsk, Russian Federation
}

Doi:10.5901/mjss.2015.v6n4s4p72

Abstract

The article deals with the current trends of the language situation and problems of preservation of minor languages in Yakutia - the largest region of the Russian Federation. The peoples living in the region (the Yakuts, Russians, Yukagirs, Evens, and Evenkis) have 400 years of the interethnic and intercultural cooperation experience. The interference is observed at the language, folklore, ethnic musical, and other levels. Bilingualism and multilingualism of various kinds, as well as assimilation processes, are intensively developing. Currently, the most typical types of bilingualism and multilingualism in Yakutia are the Yakut-Russian, Russian-Yakut-Evenki, Russian-Yakut-Even, Russian-Yakut-Chukchi types and various variations thereof. One of the features of the language situation in Yakutia is described as the current state of the Russian language of old residents of the lower reach of Indigirka, which is characterized by metalinguistic consciousness. The article also considers the features of the contacts of the Russian old-timers in the lower reaches of Indigirka and Kolyma with the spiritual culture of the aborigines of Yakutia with regard to folklore texts and traditional music at the plot and harmony intonation level. As the experience of the text folklore interaction, the peculiar features of the Russian songs due to the impact of the Yukagir folklore are described. Examples of reciprocal processes of the Russians living in Kolyma and Indigirka with the musical folklore of the Yakuts and Yukagirs are provided.

Keywords: globalization, interference, bilingualism, multilingualism, old-timers' dialect of the Russian language, traditional folklore, connotation, dance music, traditional melodies.

\section{Introduction}

The development of the northern territories of Russia began in the XVI century. During a relatively short historical period, the territories of Siberia and the Far East were explored. Officially, Yakutia became part of Russia in 1632. Then, the process of interaction of the indigenous local population with the first Russian settlers started. Moving north along the Lena, Kolyma, Alazeya, and Indigirka rivers, the pioneers actively engaged in language and cultural contacts. To establish a settlement at the mouths of the Kolyma and Indigirka rivers, the settlers formed unique sub-ethnic communities known today in the scientific world as the Russian Arctic old-timers - 'Pokhodchane' and 'Russkoustintsy'. Prior to the 1930-1950s (elimination of illiteracy and mass influx of the Russians from the motherland), the contacts between the alien and native population took place in the fairly closed, cut-off from outside influence conditions, mostly as close neighborly relations.

The article discusses the state of the Russian and indigenous languages from the sociolinguistic point of view. The language situation in the republic is characterized by massive ethnic and Russian bilingualism and multilingualism. Since the 1990s, the role and social functions of the Yakut language have been growing.

The research of the dialectic language of the Russians populating the Indigirka River has been proposed to clarify the status of the Russian language of old-timers of northeastern Yakutia. 
The art of the Russians living in Kolyma has been thoroughly analyzed from the perspective of the study of the textual and musicological approaches.

\section{Method}

It should be noted that local resident groups of the Russians in the conditions of separation from the motherland always cause a scientific interest. For example, the popular culture, in particular, the language and folklore of the Russians in Indigirka are comprehensively represented in the collection of works "Folklore of the Russkoye Ustye" (Folklore of the Russkoye Ustye, 1986). The research of "Russian old-timers of Siberia" (Vakhtin, Golovko, and Schweitzer, 2004) considers the social and symbolic aspects of the identity of several groups of descendants of the Russians that inhabited the northeast of Russia.

Now, it is the time when the need to study the local singularities of closed population groups against the background of the linguistic situation in the Sakha (Yakutia) Republic for an extended period based on the knowledge of several languages (Russian, Yakut) has coincided with the capabilities of scientists representing this region. We possess expedition materials and the skills of collaborative research that have led to certain, not conflicting conclusions.

When solving the sociolinguistic problems of the research, the authors relied on the fundamental scientific methods of cognition, applying them to the analysis of the linguistic situation: the historical, system, and comparative methods. The sources were the works of domestic and foreign scientists, collections of scientific papers, materials of conferences and meetings, materials of the national and local press, materials of state statistics of the USSR, the Russian Federation, and the All-Union census of 1989, 2002, and 2010.

The current state of the Russian language of the Indigirka old-timers is considered through the methods traditional for dialectology: the methods of direct inclusion and direct observation, the descriptive and comparative methods.

The textual and ethnomusicological analysis considers the folklore of the old-timers of Kolyma, shows the reciprocal links with the folklore of Yukagirs, Yakuts, and Evens, and the adoption of the folklore in the time of its popularity - the XIX and early XX centuries. To study the textual and ethnic musical folklore, we used the contrastivecomparative method of research.

\section{Results}

The structure of the linguistic situation in the northern region of the Russian Federation is determined by several factors. It is no accident that the first of them is called the demographic factor: the ethnic composition, the number of speakers of a given language, the nature of the settlement. The ethnic composition of the population is the macrostructure, which determines the number of components of the socio-communicative system, i.e., the number of languages used in the territory, as well as the extensity and intensity of their use. The share of the Yakuts is 48.7\%, the Russians - 37\%, the Evenkis - $2.2 \%$, the Evens - $1.6 \%$, the Dolgans - $0.2 \%$, and the Yukagirs - $0.13 \%$. Yakutia has two state languages (Russian and Yakut) and five official languages of the small-numbered peoples of the North. The 1990s, the transition period associated with the state transformation of Russia, have led to significant changes in the linguistic situation of the Turkic-speaking republics. This period was characterized by a resurgence of ethnic consciousness of peoples, the parade of sovereignties of the national republics of Russia. Preservation and revival of their native languages is inextricably linked with the whole set of economic, political, social, and cultural tasks, the purpose of which is to achieve normal happy life of these ethnic groups as equal subjects of the Russian Federation. One of the objective indicators and conditions for strengthening the national identity is the effectiveness of the language policy, language development among small-numbered peoples. The language situation in Yakutia is formed in the circumstances of the actively occurring globalization processes accompanied by intense interethnic contacts, starting from the 1950s, when the industrial development of the northeastern region of Russia was launched. The major milestones related to the further development, settlement, and industrial transformation of Yakutia began in the Soviet era. The ethno-linguistic structure of the population of the national territorial community is the historically developed main and unique component of the language situation (Baskakov and Nasyrov, 1995). The ethnic composition of the population is the macrostructure, which determines the number of components of the social and communicative system, i.e., the number of languages in use in the territory, as well as the intensity and extensity of their use. The urban population of Yakutia numbers 64.2\%, and the rural population-35.8\%. The main part of the Yakut population lives in the Central and Vilyuisk group of districts of Yakutia. In 2002, there were 60.7 thousand people (6.2\% of the population) in the northern areas inhabited by indigenous peoples, of which 21.2 thousand people were the rural population of the indigenous peoples of the North. The population 
is engaged in the traditional sectors of the economy: reindeer husbandry, farming, fishing (Argunova, 1995). Yakutia, according to the 2002 census, is home to 21,486 representatives of indigenous peoples of the North, of which 12,630 are the Evenkis, 6,677-the Evens, 414-the Chukchis (Statistical Collection, 2005). Yakutia has improved the demographic indicators relating to the increase in the indigenous peoples' share in the ethnic structure of the population: According to the current archive of the State Statistics Committee of the Sakha (Yakutia) Republic, there are 432,000 Yakuts, 18,232 Evenkis, 11,657 Evens, 1,097 Yukagirs, 1,272 Dolgans, and 602 Chukchis living in Yakutia. The interaction and interrelations of the Yakut, Russian, and indigenous population's languages creates a unique linguistic situation in the republic. As a result of the interaction of languages, which has been lasting for centuries, bilingualism and multilingualism of various kinds, as well as assimilation processes develop intensively.

Currently, the most typical types of bilingualism and multilingualism in the Sakha (Yakutia) Republic are the YakutRussian, Russian-Yakut-Evenki, Russian-Yakut-Even, Russian-Yakut-Chukchi types and various variations thereof (Sleptsov and Robbek, 1994). The Russian language is declared the official language in the republic and is the language of interethnic communication between different ethnic groups. In Yakutia, there are unique areas where descendants of Russian old-timers are densely populated. The young researchers of the North-Eastern Federal University are engaged in studying the language and folklore of the ethnic subculture. In this regard, the scientific works by T.A. Berdnikova, which deal with the historical conditions of formation of the old-timers' dialects of the Russian language and their existence in modern conditions (Berdnikova, 2014).

The Yakut-Russian bilingualism in Yakutia has gone through several stages and is now a widespread linguistic phenomenon, one of the basic elements of the language situation in the republic. According to T.V. Argunova, today, Yakuts, in comparison with the titular peoples of the former autonomies, are among the ethnic groups with the largest number of monolinguals with the native ethnic language and the smallest number of those with the native Russian language (Argunova, 1992). This is explained by the relatively low degree of urbanization, low involvement in industrial and science-based labor areas, the specifics of the mostly rural-type settlement with the preserved traditional way of economic management (Argunova, 1992). The Yakut language is considered native by $94 \%$ of interrogated Yakuts according to the 2010 census. There is a somewhat different situation with the indigenous peoples of the North: the Evenkis, Evens, Chukchis, and Yukagirs. Compared to 1989, the number of Evenkis who consider their ethnic language native reduced by $2.5 \%$, Evens - by 14\%, Yukagirs - by 15.7\%, and Chukchis - by $25.5 \%$ (Sleptsov and Robbek, 1994). Table 1 shows the data of the 1989, 2002, and 2010 censuses, reflecting the change in the indicators of the linguistic identity, linguistic proficiency of the Yakuts, Evenkis, Evens, Yukagirs, and Chukchis. According to the researchers, the small-numbered peoples have been involved in the process of the language shift towards the Yakut language over the last decades in some rural areas with the traditional way of living and towards the Russian language in the industrial zone: $72.2 \%$ of the Evenkis and $60 \%$ of the Evens recognize the Yakut language as native, $51 \%$ of the Chukchis specify Russian as native (Sleptsov, 2007).

Table 1. Distribution of the indigenous ethnic groups by the language proficiency, $\%$

\begin{tabular}{ccccccc}
\hline \multirow{2}{*}{ Ethnic group } & \multicolumn{2}{c}{ Consider the language of their ethnic group as native } & \multicolumn{3}{c}{ Speak Russian } \\
\cline { 2 - 7 } & 1989 & 2002 & 2010 & 1989 & 2002 & 2010 \\
\hline Yakuts & 95.0 & 92.6 & 94 & 65.0 & 87.1 & 89.3 \\
\hline Evenkis & 8.5 & 6.0 & 11.1 & 64.3 & 89.1 & 94.9 \\
\hline Evens & 34.7 & 20.7 & 22.2 & 56.7 & 89.3 & 94.1 \\
\hline Yukagirs & 35.2 & 19.5 & 22.5 & 43.5 & 95.4 & 97.2 \\
\hline Chukchis & 63.2 & 37.7 & 29.6 & 63.2 & 98.3 & 99.8 \\
\hline
\end{tabular}

(The ethnic composition and languages skills.., 2005,. p. 20-23).

The search for strategies and principles that would ensure the vitality of minor and less-used languages in multiethnic states in the circumstances of the objective expansion of the linguistic space of the dominant languages requires scientific and professional approach with account of the linguistic and extra-linguistic factors. In this context, the preservation and revival of the language of the traditional culture of the indigenous peoples of Yakutia is one of the most important and fundamental problems of contemporary human science. The language situation in the areas of compact settlement of indigenous peoples of the North can serve as an indicator of the overall socioeconomic disadvantage, the loss of the ethnic identity and culture of these peoples. The degree of language skills universally correlates with the age of the native speakers: the linguistic groups have stratified into age groups (generations), where the elder are the bearers 
of the language and cultural traditions, i.e. a group that is characterized by centripetal, conservative tendencies, and the younger, on the contrary, are the bearers of innovations, the centrifugal tendencies in culture, and, accordingly, are focused not on the native language, but on the language of the larger ethnic group (in Yakutia — on the Yakut language) (Mayorov, 1998). Existence of the Yakut-Russian bilingualism and other types of the ethnic-ethnic bilingualism in the Sakha (Yakutia) Republic, as well as multilingualism is determined by the linguocultural commonality of the multi-ethnic population and is the result of the entire previous stage of interaction of languages in the republic. Currently, in the language-related activities in the republic, the interaction of the two state languages, Russian and Yakut, the speakers of which are the vast majority of the population, is most common. Therefore, bilingualism involving these components is one of the most typical of its trends. In the areas of compact settlement of the indigenous peoples of the North, national languages and the languages of local ethnic subcultures, as well as multilingualism are present.

The varieties of the Russian national language include the primary, secondary, and mother dialects, the dialects of the late settlement territories. The latter include all Russian dialects spread beyond the Ural Mountains. The history of their formation relates to different periods: some had been formed by the XVI-XVII centuries, others - by the XVIII-XIX centuries, and others - by the XX century. "The peculiarities of the formation conditions caused to some extent the originality of the dialects," (Samsonov and Samsonova, 2007). An old-timers' dialect is commonly understood by modern dialectology as "a dialect in Siberia that possesses a set of phonetic-grammatical and lexical-phraseological peculiar features identified through the study of the speech of the ancient descendants of the old time population of Siberia (XVI first half of XVIII centuries) and distributed across the entire Siberia" (Blinova, 1973). Russian old-timers live throughout the republic and compactly - in 17 districts. According to the typology of M.F. Druzhinina, there are two zones of oldtimers' Russian dialects in Yakutia: the Lena area (settlements downstream the Lena river, including Yakutsk) and the Arctic area represented by the lower Indigirka (Russkoustinsky) dialect and the lower Kolyma (Pokhodsky) dialect (Druzhinina, 1997). These dialects are not a single monolithic structure, which is associated with the peculiarities of the region settlement: Yakutia, as well as other areas of Siberia, has experienced several waves of migration, which resulted in the coexistence of various types of dialects in its territory.

The lower Indigirka old-timers' dialect has become the target of studies several times (the scientific literature considers the lower Indigirka and Russkoustinsky, the lower Kolyma and Pokhodsky dialects as full synonyms). For example, the language research is reflected in the works of V.G. Bogoraz ("Regional dictionary of the Kolyma dialect of the Russian language"), V.M. Zenzinov ("Ancient people near a cold ocean"). A systematic study of the Russian Arctic dialects of Yakutia began under the leadership of M.F. Druzhinina, and the long work resulted in a unique publication the four-volume "Dictionary of Russian old-timers' dialects in the territory of Yakutia." Simultaneously with the vocabulary and phraseology, the phonetics and morphology of the dialects were studied. The Russkoustinsky dialect is still actively used today. According to the results of the 2014 expedition, we can distinguish the peculiar features of the modern state of the Russkoustinsky old-timers' dialect. Firstly, it is the presence of high-level metalinguistic consciousness of the dialect speakers (the metalinguistic awareness is understood as a synonym for the surface level of language awareness B.T.), which includes the percepts of the speech and language reality and is part of the naive linguistic picture of the world and the world vision of the dialect speakers in general. The main feature of the metalinguistic consciousness is the belonging to the population of the entire rural area, non-distinguishing themselves from the society, which is typical of the general behavior of a Russkoye Ustye inhabitant. Repeatedly in conversations with informants, we recorded the pronoun "NASHI" ("Ours"). To the direct question, "Who is understood as "NASHI"?", the following responses were received: relatives, friends, classmates, neighbors that on closer examination turn out to be the inhabitants of Russkoye Ustye or come from there: "Rusko Ustye priezhzhaesh - eto zhe dom rodnoy!" (When you come to Russkoye Ustye, you feel like you're home!), "Otdykhali nynche nashi v Anape" (Our people have recently gone for a vacation in Anapa); "U nas zhe on (govor) sokhranyaetsa" (We preserve our dialect); "V Rossii nashikh malo" (There are a few of our people in Russia); "Nashi govoryat, mysh prygnula" (Our people say, a mouse has jumped), etc.

The sense of commonality manifests itself in the understanding of the linguistic standards common for the entire group and expressed in the common vocabulary, phonetics, grammar, methodology, and rhythm of speech.

"NASHI" is determined within the framework of the extensive system of group and individual nicknames: bukushki (other called so the Russkoye Ustye inhabitants), Dyudyurashka, dedushka Suma, Komikha. In some cases, they have an internal form understandable only for a member of the linguistic community: Soloveyka (probably sang well, like a nightingale); Sobolyonok (he was probably dark like a sable), Arishin Yegor (named after his mother Arisha), Agapit (after the movie; the nickname was given by peers), Utochka (little duck, so calm, though the name was Sasha), Mukha (a fly, the younger sister), Tarbey (a bird of prey, the nickname was given after the event, when the boy grabbed the salmon being smoked dry from the hanger while running like a bird of prey); Snegiryok (a bullfinch, the harbinger of spring, something light, good). It should be noted that nicknames is tradition of the Russkoye Ustye inhabitants (they gave 
double names - Panteley and Sobol (sable)), people did not feel insulted with it. At the same time, we noticed that they most often addressed (at least, in the presence of people not from Russkoye Ustye) each other in the name-andpatronymic form: Tamara Kupriyanovna (about the cousin), Yevdokia Sergeyevna (about the 30-year-old niece), Yevdokia Petrovna (about the friend).

The use of pejorative, gentle forms is also typical of the modern Russkoustinsky dialect: nashi kroshechki (our tithes) — about children, Matolya - gentle for Matryona, Kenyushka — gentle for Innokenty, Utochka (little duck) — a nickname, Batya Olka — for Alyosha, Alyoshenka (a junior called his adult relative).

The metalinguistic consciousness also manifests itself in the attitude of the speakers to their speech: Unlike speakers of other dialects, the inhabitants of Russkoye Ustye do not consider their dialect a prestigious one. They love and respect their language. The reason for this attitude, according to the researchers, is of clearly extra linguistic nature: in the linguistic environment of non-related languages (Yukagir, Evenki, and later Yakut), it was important to preserve their own, native features that were (and still are) the markers on the "us-them" scale. This scale was and is applied even when communicating other Russians, but in a deformed form: the substantivized adjective "TAMOS(H)NIYE" (strangers) shows that there are our Russians, the inhabitants of Russkoye Ustye, local, "NASHI" (ours), and non-inhabitants of Russkoye Ustye, strangers, TAMOS(H)NIYE (strangers). This statement is confirmed by the presence of names of other people (Yukagirs, Chukchis, Evens, and Yakuts) and absence of names of the Russians coming from other places.

Dialect speakers also feel permanent scientific interest in the phenomenon of Russkoye Ustye. Various scientific expeditions have repeatedly come to the village, including renowned persons (e.g., V.G. Rasputin). Among them, their own scientists appeared, for example, A.G. Chikachev. Articles, notes, and books about Russkoye Ustye and its residents entered the public domain. Older people argue about the accuracy of certain words, some of them record their own notes to preserve dialect words.

Over the past 80 years (since the early 1930s), the Russkoustinsky dialect has undergone significant changes according to the older generation of the dialect speakers. Here, we can make a few assumptions, which, again, are not of the linguistic nature. Firstly, the Russkoustinsky dialect for many years had been virtually isolated, avoiding the influence of both the literary Russian language, and other Russian dialects due to its territorial remoteness. But in Soviet times, contacts with other Russians became more frequent. The vocabulary of the dialect became increasingly supplemented with new words reflecting primarily the socio-political realities and technical innovations. Due to the introduction of specific forms of economic management, the Russkoustinsky dialect remained in a better position than other Russian dialects, where the change of the social system resulted in almost complete loss of the rural life style.

The universal elimination of illiteracy has given the opportunity to the villagers to obtain a certain profession, especially in contrast to employment in traditional crafts only. Education is always associated with studying the literary form of the national language. Dialect speakers repeatedly recalled how they were criticized by visiting teachers for the specific pronunciation, use of a dialect word, expression, or exclamation. But the not found proper methodological techniques of training (especially in spelling) in the circumstances of the dialect environment yet were not so devastating, in our view, as they are remembered. I think that the elimination of illiteracy, school education, and subsequent, most often, professional high-school education, formed diglossia, i.e. "simultaneous existence in a society of two languages or two forms of the same language used in different functional areas" (BES, Linguistics, 136). From a language covering all aspects of life of a Russkoye Ustye inhabitant, the dialect has become a means of everyday, domestic communication. That is why modern inhabitants of Russkoye Ustye quite freely communicate with all Russian-speaking people, not just with fellow villagers and relatives. However, in situations of informal communication (at home, in a store, outside, in a hospital, sometimes even in the work team if it is made up of the inhabitants of Russkoye Ustye), they switch to the dialect. We have seen a clear switch from the dialect to the standard language when the dialog involved non-inhabitants of Russkoye Ustye.

Today, the Russkoustinsky dialect continues to function in a limited scope in everyday-life communication, and develops according to its internal laws, notwithstanding the external, extra linguistic factors (primarily the development of the progress in science and technology and, as a consequence, the disappearance of some traditional forms of economic management). The still existing fishery contributes to the dialect existence also in professional communication, which is confirmed by the number of lexical units of the semantic field "Fishing." The core of the dialect preservation is a high level of self-awareness of the speakers and their responsible attitude to their own identity, for example, conducting lessons of traditional culture in a general education school with compulsory inclusion of the language material; operation of child and adult groups of the folklore ensemble; constant interaction of the older, middle, and younger generations of the dialect speakers.

Modern folkloristics pays close attention to the folklore of certain areas and regions. The preservation of folklore in the area, which is separated from the motherland while the folklore of the displaced persons is in close cooperation with 
the language and folklore of the neighboring peoples also causes scientific interest. In this regard, it is relevant to consider the issues of interaction experienced by the folklore of Russian old-timers in Yakutia. Until recently, the genre and repertoire composition of the Russian folk songs of the Russian old-timers in the Lena region in the conditions of bilingualism and their folk music had been relatively thoroughly studied (Larionov, 2008).

In the north of Yakutia, the Russians began to settle in the XVII century. They came from the European North to the mouth of the Indigirka River. The folklore of Russian old-timers is a special part of the Russian folklore heritage. The Russians came to Kolyma at around the same time, but through Yakutsk, to collect tribute and perform other works in the northern cities and settlements.

The text folklore as well as other kinds of spiritual culture contains the peculiar features reflecting the relationship of the vocabulary and genres of the folklore of another, indigenous nation.

In Kolyma, there is a beautiful but obscure song "Kuksha." It was recorded in both the XIX-XX centuries, and more recently, at the beginning of the XXI century. We recorded it in the village of Chersky of the Nizhnekolymsky District in 2005 from Yevdokia Mikhaylovna Paklina (Daurova), 45 years old:

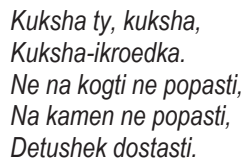

In conclusion, Paklina added that this was a lullaby.

The song has 25 verses. It is sung in a measured, calm manner; it is structured, as Russian songs are commonly composed. It is a two-part composition, in which "kuksha" firstly does not give a girl the things she needs. In the second verse, "kuksha" answers that it will bring the desired "kogti" (claws) to the singer. The main character acts as a mother who has to get to her "detushki" (children), while her husband is absent. However, much of the song is understood differently, especially when we consider the earlier versions.

M.F. Druzhinina provides a part of the song "Kuksha" recorded in the Nizhnekolymsky District in the middle of the XX century. The record evidences that the song was of a clearer nature associated with the vicissitudes in the birds' circle: loons and Siberian jays (Russian - "kuksha"): "Siberian jay - a forest bird with partlet on the head and gray wings" (Druzhinina, 2007). She believes that "GAGAGLYA — loon (Russian—"gagara")" (Druzhinina, 2002).

We also have a record of the same song made by V.G. Bogoraz in the late XIX century from Elena Daurova in the "Regional dictionary of the Kolyma Russian dialect":

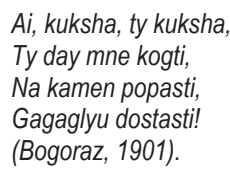

The song has 14 verses without repetitions. There, in the Dictionary, Bogoraz explains: "Gagaglya (gagagyya) outerwear made of reindeer skin (female)" (Bogoraz, 1901). He related the song "to "robachyi," which are sung for lulling or nurturing children," and added, "They have kept a clear trail of the Yukagir origin" (Bogoraz, 1901). By the way, the "Even-Russian dictionary" explains the word: "Gagagli (<Koryak) - "kukhlyanka" (female wear, fur inside) (Robbek, 2005). As you can see, the word is Even and Koryak.

From the example provided by Bogoraz, we see that in the first verse, the singer addresses "kuksha" and the second verse begins with an address to "petishka" Thus, it becomes clear that the song is based on the contrast of these characters. "Kuksha" refuses to help the singer, while "petishka" helps her. The third verse, in which the singer opposes herself to the "sour" who "disappeared," strongly emphasizes the idea that the girl had just got out of a difficult situation, but there is no hint of the children or her husband.

Bogoraz also recorded a Russian fairy tale of the Yukagir origin. Here is the beginning of the tale:

"Raz yukagiryi zhili: u nikh bula odna dochka. Ona vyshla po sneg.Prishel vikhor i unes ee.Podneslo k kamnyu: ot zemli do neba stoit kamen." (Once, Yukagirs lived: they had a daughter. She went out on the snow. Whirlwind came and took her away. Brought her to the stone: the stone was from earth to heaven). Next is the dialogue of the girl and birds, where the second bird brings the desired thing. Then the wind brought two more girls. The first girl prudently gets rid of them. She escapes and sings: 
"Kakaya udalaya,

Kakaya bedovataya!

Na kamushek popala..."

(I am so varmint, I am so daring. Got on the stone...)

Then she sings about "kuksha" and "petishka." The fairy tale develops as follows: she gets into a house, which belongs to a "one-sided man." All work on the house is done by "frogs, mice, ermines, different worms, mosquitoes, flies, and so on." The girl "cooked them." Then the "one-sided man" appears and requires the services, but no one serves him. He finds the girl and tells her that she should do all the household chores by herself. Then, she must go with "three herds" along the specified path. She copes with this work, singing a song:

\author{
"Kakaya udalaya, \\ Kakaya bedovataya! \\ Utrom rano soskochila \\ I vsya ubralasya." \\ (I am so varmint, I am so daring. Got up early in the morning, and cleaned the entire house).
}

Then, it is reported about the construction of "ruyta" (tent), and waiting for the arrival of her husband. Finally, there is a young man, her husband - Lygynaka. He has to prove his status: He turned to a "one-sided man." In the end, the young come to the place where there is a camp of lamuts. "Perednya ruyta stoit chyorny chum, pechalny takoy - iya otets-mati zhivut, prikochevali. Starukha i starik vyskochili, obrasovalis; tut zhe srazu razsypalis kak pepelok. Tolko." (The first ruyta is a black tent. Their mother and father have come and stayed. The old man and woman came out and appeared; then crumbled like ashes. Just).

(Written from the words of peasant Maria Viligina in Sukharnaya) (Bogoraz, 1901).

Consequently, we can see that this story told in Russian is really of Yukagir origin. From the context, it is clear that the tale is somehow related to the subject of searching for a groom, creating a family.

There is also a Yukagir record "Ob odnoy podnyavsheysya skazka" ("A tale of one risen") by V.I. Iokhelson in 1900. It is a short rigorous story about the vicissitudes in the life of the main character, in which it is told about three sisters. The youngest saves herself using "caviar" and "awl" and then finds a home, to which later a "guy came" (lokhelson, 2005). There is no song of the girl, no motive of nomadism, no search for relatives, and thus no return to the beginning of the fairy tale. However, many things become clear: Use of glue and sharp objects to rescue from the mountain, the elimination of the rival sisters, rival servants (mouse, frog).

L.N. Zhukova highlights the main motives, which is the connotation of the theme: "native land" and "road" associated with the motive of passage "traces of all animals" (Zhukova, 2008). She also notes, "The groom not only lives in some unknown, foreign land, but is probably a representative of another nation," and determines that the servants in the house "frog girl," "mouse girl" are also representatives of another nation (Zhukova, 2008). However, we do not know the ways of transition of the fairy tale to the Russian folklore of the Kolyma inhabitants and how the song separated from the fairy tale.

In Bogoraz's fairy tale, the girl's song is sung three times, and has a continued story line resonating with the plot of the fairy tale itself: the girl beats rivals with common things; the girl stand the test of her husband - reindeer transfer, yurt building. The tale is ended with the typical Yukaghir folklore technique: "Starukha $i$ starik <...> rassypalis kak pepelok" ("The old woman and the old man $<\ldots>$ crumbled like ashes"). In the lexicon of songs, the emotional nature of the motives, in which she triumphed, shows that the song, despite its measured rhythm, was not only a lullaby, but also an emotionally colored, lively song.

V.I. Iokhelson wrote that this and other tales "are told much more beautifully and thoroughly by the Russians of Kolyma and even by the Chukchis" (Iokhelson, 2005). However, the tale becomes multi-layered by the richness of meaning due to its Yukagir origin.

Thus, we can conclude that the Russian song is borrowed from the Yukagir folklore and began to be sung separately. Herewith, "petishka" and "kuksha" merged into one image. The song acquires composition characteristic of Russian songs.

The folk music of Russkoye Ustye is also rich and diverse in genre composition. Despite the preservation of Russian performance traditions, it differs in its uniqueness and originality, which is due to the processes of mutual influence and interpenetration of the cultures of the indigenous peoples of Yakutia: the Evenkis, Evens, Yukagirs, and Yakuts, as the Russians lived in Russkoye Ustye in an ethnically different environment. New and original genres unique to this area were created_- "andylshchina" and dance tunes "Omukanovo" and "Rassokha." 
In general, the traditional folklore of the Russian population of Siberia has been studied in terms of both ethnography and folklore, and philology and music. There is a fairly wide variety of musicological studies, performing the musical, genre, and thematic research in the field of folklore of the Russian old-timers of Siberia and the Far East. However, despite the rather broad knowledge of the traditional folklore of the Russians of Siberia, the musical folklore of the Kolyma Russians has been studied insufficiently. In this respect, separate genres are most studied in this local musical tradition: epics, "vinogradya"—Christmas greeting songs and instrumental melodies in the records collected by V.G. Bogoraz and V.I. Iokhelson in 1900-1902. They were studied and notated by E.I. Yakubovskaya in the article "Traditional folklore of the Russian population of Anadyr and Kolyma, recorded by V.G. Bogoraz and V.I. Iokhelson" (Yakubovskaya, 2008), which included 25 samples decryption. Also, the instrumental melodies of "Kamarinskaya" were published in this article. The collection of N.V. Vinokurova "Song traditions of Kolyma" (Vinokurova, 2014) published "andylshchina", Middle Kolyma and Pokhodsky "vinogradya", folk songs, dance tunes, songs of exiled people, camp and lyrical songs.

T.S. Shentalinskaya beside epics, "vinogradya" —Christmas greeting songs, instrumental tunes of "Kamarinskaya," lyrical songs, and other genres of music folklore of Russkoye Ustye studied rather well such an original song genre as "andylshchina," typical of only northeast Yakutia. They were created under the influence of the song culture of another ethnicity environment. T.S. Shentalinskaya indicated that "the genre base (an improvised monologue, separation of individual belonging in the songs), typical situations of creative performance (in the circumstances of hunting/fishing retreat, in the way, or as a declaration of love in the form of a song) will undoubtedly bring together "andylshchina" and the culture of Siberian aboriginals. One of Kolyma inhabitants said: "Andylshchina in Yakut means "I sing what I think, what I see ahead of me"' (Shentalinskaya, 1995).

And, indeed, "andylshchina" songs are similar to the Yakut song culture represented by the "tuoysuu yryata" genre. "Tuoysuu yryata" are love songs of a woman or a man: "dahtary tuoyuu," "er kihini tuoyuu." There is only one record of "tuoysuu yryata" — the "Tuoysuu yryata" (Song of sadness) song recorded in Verkhoyansk from Kh.E. Afanasyeva in 1987, in which a comic start of a love story of Nikolay and Nastasya had a slightly erotic tinge, and then shifted to the opposite sentiments, raising the problem of a difficult women's share.

The tune itself bears the archaic features. The song's melody is doubly, characteristically decorated with grace notes reminiscent of "kylysah" (guttural overtones). The fact that unusual timbre decorations may also occur in "andylshchina" songs is confirmed by T.S. Shentalinskaya. Analyzing the ensemble performance of "andylshchina" songs, she wrote, "Specific guttural decorations within a syllable with a low voice performed by an older woman are noteworthy" (Shentalinskaya, 1995), which also confirms the position of some analogies of the analyzed genres.

The structure of the text is heptasyllabic, sharply alternating with octosyllabic. Changing in the basic duple beat is related to the physiological nuances of performance, in particular, with pauses during breath taking. In addition, the metric changes can occur because of the desire of the performer to put an octosyllabic verse in the melody without changing the basic skeleton of the melody. Similar structures are present in "andylshchina" songs, in which the "melodic and poetic period is focused on the rhythmic outline of a syllabic verse of the "8+7" type with the division of hemistichs into the following syllabic groups: $4+4+4+3 "$ (Shentalinskaya, 1995). In Yakut singing, in addition to the andylshchina-like structures, there are other divisions of the octosyllabic and heptasyllabic structures in the following form:

Heptasyllabic: $2+2+3 ; 4+1+2$

Octosyllabic: $5+3 ; 2+3+3 ; 3+2+3 ; 2+2+4$

In "andylshchina" songs, unlike Yakut, the four main emphases expressed by certain pitch positions do not coincide with grammatical accents, which gives them certain originality.

The difference between a Yakut tune and "andylshchina" consists in the tune mostly. While "tuoysuu yryata" is based on doubly major second pendulumlike melody from the beginning to the end of the song, the melody of an "andylshchina" song develops in a broad ambitus. T.S. Shentalinskaya argues, "The main distinguishing "attribute" of "andylshchina" is its unique tune. The bizarre, zigzag pattern of the melody fills the extremely wide for domestic singing sound space (in some samples, up to two octaves), tertian, quartal "steps" that have almost entirely supplanted second connection, wide interval steps, some turns (lifts and drops, reaching eleventh - all this makes them spontaneously unpredictable and, most importantly, strange, dissimilar to Russian songs. The intonation originality, special style of singing (not always accurate pitch fixedness of sounds and their sliding), which is now typical of many artists of the older generation, combined with the specific soft speaking even more difficult to understand at singing, hit and is hitting an uninitiated ear with its exotic" (Shentalinskaya, 1995). This slide from pitch to pitch, the lack of accurate fixation of sounds is typical of the northern ethnic groups' singing: the Evenkis, Evens, Yukagirs, and Yakuts. For example, the Yukagirs' tunes also are played in a fairly wide range. "Melodies of Oduls (Middle Kolyma Yukagirs - A.L.) are based on the quint and octave hemitonic scales with the tone center in the middle" (Sheikin, 1996). 
According to the observations of O.I. Charina, the folklore of the Russians in Yakutia does not demonstrate "any significant Yakutization of the images and vocabulary of the texts of Russian songs. However, the folk rhymes vocabulary often includes some Yakut or Yakut-like words and phrases" (Charina, 2009). In the Russkoye Ustye's folklore, foreign ethnic words are not very popular. In this regard, an interesting phenomenon was the song "Kuksha", which is a genre of a lullaby that includes Yukagir words in the V.G. Bogoraz's record. There is a notation of the song produced by N.V. Vinokurova (Vinokurova, 2014). The song was performed by E.M. Pashina (born in 1959) in 2011 during an expedition to the Chersky settlement. The version of the song recorded by O.I. Charina in the Chersky settlement from E.M. Paklina (Daurova) in 2012 is sung at the same pitch as the previous version of the tune written in the natural e-moll key with the same intonations. The initial of the melody begins as the previous version with the lyrical $\mathrm{m} .6$ tone. The melody ends with the e keynote. The rhythm of the song is clear, at the rate of $2 / 4$, with alternating short and long lengths in variants: DKK|DD; KKKK|DD ( $\mathrm{D}$ - long sound, $\mathrm{K}$ - short sound). The difference between the two versions of the song "Kuksha" is that the first version starting from the sixth row of the verbal text to the words "Ya o chyom tebe kazaya" (What I told you about) is transposed from e-moll in $\mathrm{f}$-moll. In the second case, there is no such transposition. Also, in the presentation of the second song version, the song is performed not from the very beginning: it lacks the first three rows and the initial of the fourth row. Here, you can find that in the later recordings of 2011-2012, the Yukagir influence is traced neither in the vocabulary, nor in the tune. They are typical Russian melodies.

The popular for Russkoye Ustye dance-tune "Omukanovo" appears an original and distinctive phenomenon. With a Yakut song title, it is a typical Russian dance tune by intonation. The originality of the melody is provided by the absence of the instrumental accompaniment, and presence of only its imitation in the form of synsemantic words without sense in the dance rhythm. Interpretation of the text is virtually absent; only a clear dance rhythm of the song prevails. The tune is sung over the syllables like: hil-la-la-dar hil la-la-da. Using the pharyngeal "h" is very common in the dance culture of the indigenous peoples of Yakutia, for example, in Even "See D'e", in Yukagir "Londol," and Yakut "Osuokhay." In another version of the "Omukanovo" dance, the following syllables are present: dikh-dokh dir-li-li-dar; tur-la-la-dam tir-li-ti-dam. All this is accompanied by the clatter of feet and occasional exclamations of the dancers of the syllables "eh-ikh-ikh-okh." This fiery tune gradually involves all the present in the dance.

Another dance tune "Rassokha" has a meaningful verbal text already. Syllables without sense accompany the melody in one version of the song in the form of "ti-dya, ti-dya, ti-dya-dam," where the dance reaches its climax slowly, and at the time when all the dancers are involved, the song sounds in two voices. The second voice sounds as the upper third of the main tune. In another version of the same song performed by I.P. Borisova (born in 1957) from Chersky, the note writing of the 2011 record by N.V. Vinokurova sounds like "ti-da, ti-da, ti-da, ti-da, ti-da ta" (Vinokurova, 2014).

Consequently, in the areas of ethnic contact like Yakutia, local sub-ethnic groups are formed, which include Russkoye Ustye, that are successfully integrated into the surrounding cultural environment. The Russkoye Ustye folk music shows its adaptation capacity by creating new original genres and at the same time preserving its ethnic identity.

\section{Discussion}

Thus, in Yakutia, a number of measures were taken on the state level, and the educational practice of training contributes to preserving the languages of the indigenous ethnic groups. However, at a deep level, the processes of transformation are going on, which are reflected, above all, in the language, culture, and folklore. Globalization processes affect not only the material order, but also the spiritual sphere.

The modern Low Indigirka (Russkoustinsky) dialect, which is preserved in the circumstances of territorial remoteness and foreign environment, develops according to its own internal rules. The metalinguistic consciousness is typical of the dialect speakers. Herewith, the dialect speakers consciously take measures to preserve the language of oldtimers of the Arctic in daily practice.

The Russian folklore of the Kolyma old-timers had experienced significant influence on the part of the indigenous language and folklore until the early XX century. The Russian song that we have studied was taken from the Yukagir folklore, and it began to be performed independently from the original fairy tale. The song gained a composition typical of Russian songs and is sung currently.

Thus, through the example of Russkoye Ustye in Yakutia, we can see how local sub-ethnic groups are formed in the areas of ethnic contacts and successfully integrate into the surrounding culture medium. Having preserved their traditional musical culture, the Russian settlers took over certain song genres and harmony intonation basics typical of the songs of the northern ethnic groups living in Yakutia. It was found that up to XVIII-XIX centuries, these effects were more significant, and in the XXI century, the reciprocal processes are being blurred, but not disappear completely. 


\section{References}

Argunova, T.V. (1995). Linguistic interaction in the formation of the modern ethno-cultural situation (to the problem statement) (pp. 3536). Yakutsk, Russian Federation. Cultural interaction between the peoples of the Sakha (Yakutia) Republic: history and modernity. St. Petersburg. [In Russian]

Baskakov, A.N., \& Nasyrova, O.D. (1995). The language situation and functioning of languages in the region of Central Asia and Kazakhstan (pp. 5-46). Moscow: Dominant. [In Russian]

Berdnikova, T.A. (2014). On the peculiarities of functioning of modern Russian dialects in the north-east of Russia. Modern problems of the circumpolar world. (pp. 40-44). Yakutsk, Russian Federation: Publisher North-Eastern Federal University. [In Russian]

Blinova, O.I. (1971). On the term "old-speaking dialect of Siberia." (pp. 4). Issues of linguistics and Siberian dialectology. Tomsk, Russian Federation: Publishing House of the Tomsk State University. [In Russian]

Bogoraz, V.G. (1901). Regional Dictionary of the Kolyma Russian dialect. Gathered at the site and made by Bogoraz, V.G. (pp. 342345). Collection of ORYAS. St. Petersburg. [In Russian]

Charina, O.I. (2009). Russian songs of the Lena region. Novosibirsk: Nauka. [In Russian]

Druzhinina, M.F. (1997). Russian Dictionary of old-timers' dialects in the territory of Yakutia. (pp.5). Vol.1. Yakutsk, Russian Federation: Publishing House of the Yakutsk University. [In Russian]

Druzhinina, M.F. (2002). Dictionary of Russian old-timers' dialects in the territory of Yakutia. Vol. 2, Yakutsk, Russian Federation: Publishing House of the Yakutsk University. [In Russian]

Druzhinina, M.F. (2007). Russian Dictionary of old-timers' dialects in the territory of Yakutia. Vol. 3, Yakutsk, Russian Federation: Publishing House of the Yakutsk University. [In Russian]

Ethnic composition and language skills, citizenship of the population of the Sakha (Yakutia) Republic. 2005, p. 20-23 Yakutsk: Komitet gosudarstvennoy statistiki Respupliki Sakha Yakutia. [In Russian]

Folklore of Russkoye Ustye (1986, Azbelev, S.N., Venediktov, G.L., Gabyshev, N.A., et al., Comp.). Leningrad: Nauka. [In Russian]

Great Encyclopedic Dictionary. Linguistics. (1998). (pp.136). Moscow. Russia: Scientific Publishing House "Big Russian Encyclopedia." [In Russian]

lokhelson, V.I. (2005). Materials for the Study of the Yukagir language and folklore collected in the Kolyma district. Yakutsk, Russian Federation: Bichik, V.I. Iokhelson. [Ed. Candidate of History, L.N. Zhukova; foreword by Z.I. Ivanova-Unarova].

Larionova, A.S. (2007). The folk music of the Russian old-timers' of the Lena region. Russia and Yakutia: through the prism of history (pp. 266-271). Yakutsk, Russian Federation. [In Russian]

Mayorov, A.P. (1998). Social bilingualism and linguistic space (pp. 7-22). Ufa, Russian Federation. [In Russian]

Robbek, V.A., \& Robbek, M.E. (2005). Even-Russian dictionary. Novosibirsk: Nauka. [In Russian]

Samsonov, N.G., \& Samsonova, L.N. (2007). The Russians in the Lena region. Vol.4. The dictionary of the Russian old-timers' dialects in the territory of Yakutia (pp. 172). Yakutsk, Russian Federation: Publishing House of the Yakutsk University. [In Russian]

Sleptsov, P.A. (2007). Problems of the native language in the context of globalization and integration of the modern society (pp. 45-52). Yakutsk, Russian Federation.

Sleptsov, P.A., \& Robbek, V.A. (1994). The language situation in the Sakha (Yakutia) Republic: the state, prospects, and problems. The languages, culture, and future of the peoples of the Arctic. (pp. 42-45). Yakutsk, Russian Federation. [In Russian]

Sheikin, Y.I. (1996). The musical culture of the peoples of North Asia (pp. 123). Yakutsk, Russian Federation: RDNT. [In Russian]

Shentalinskaya, T.S. (1995). Andylshchina - the local song genre of the Rusisan Kolyma inhabitants. Issue 7. Preservation and revival of folklore traditions (pp. 140-151). Moscow. [In Russian]

The results of the All-Union census of 2002 (2005). Yakutsk, Russian Federation: The State Statistics Committee. [In Russian]

Vasilyeva, R.I. (2012). The ethno-linguistic situation in the Sakha (Yakutia) Republic (based on the functioning of the Yakut and Russian languages in the Lena region). Germany: Scientific Publishing House "Lap lambert Academic Publishing Gmb \& Co.KG."

Vakhtin, N.B., Golovko, E.V., \& Shvayttser, P. (2004). Russian old-timers of Siberia: The social and symbolic aspects of self-awareness. Moscow: Novoye publishing house. Retrieved from http://www.kniga.com/books/preview_txt.asp?sku=ebooks317473 [In Russian]

Vinokurova, N.V. (2014). Kolyma song traditions (based on musical and ethnographic expeditions of 2009-2012.) (pp. 104). Yakutsk, Russian Federation: RIO Media Holding. [In Russian]

Yakubovskaya, E.I. (2008). Traditional folklore of the Russian population of Anadyr and Kolyma as recorded by V.G. Bogoraz and V.I. Yokhelson (pp.181-246). Russian folklore. Materials and studies. St. Petersburg: Nauka. [In Russian]

Zhukova, L.N. (2008). The spatial image of the world of forest Yukagirs (based on spoken folklore). Languages of indigenous peoples of the north at the beginning of the III millennium (pp. 115-127). Novosibirsk. [In Russian] 